\title{
The Value-Adding Role of the Corporate Headquarters in Innovation Transfer Processes: The Issue of Headquarters Knowledge Situation
}

\author{
Christine Holmström Lind ${ }^{1}$ - Olivia H. Kang ${ }^{1}$
}

Received: 22 March 2013/Revised: 10 October 2016/Accepted: 24 January 2017 /

Published online: 20 February 2017

(C) The Author(s) 2017. This article is published with open access at Springerlink.com

\begin{abstract}
The aim of this study is to investigate the value-adding role of corporate monitoring and corporate involvement in 'sticky' inter-subsidiary innovation transfer environments. The value added role of these two managerial approaches is viewed in terms of their impact on innovation transfer efficiency and effectiveness. Based on the network view of the MNC, our research builds on the notion that the corporate headquarters (CHQ) is ill-informed and may suffer from a radical uncertainty about what it actually knows and needs to know. By using a data sample containing 87 innovation transfer projects in 25 multinational companies, we test six sets of hypotheses. Overall, our findings show that the value added of CHQ monitoring as well as an active CHQ involvement is considerably constrained. However, contrary to our expectations, the results show that CHQ monitoring gives rise to an increase in both transfer efficiency and effectiveness when the 'stickiness' is based on tangible resource constraints. The results imply that when it comes to CHQ involvement during the innovation transfer processes, the choice between a handsoff and a hands-on approach has to be understood in the light of the CHQ's knowledge situation.
\end{abstract}

Keywords Multinational corporations · Headquarters role · Corporate headquarters · Innovation · Innovation transfer

Christine Holmström Lind and Olivia H. Kang have equally contributed to this article.

Olivia H. Kang

olivia.kang@fek.uu.se

1 Uppsala University, Uppsala, Sweden 


\section{Introduction}

Scholars have long been concerned with the role of the corporate headquarters (CHQ), particularly in the context of diversified and differentiated multinational companies (MNCs) (Chandler 1962, 1991; Penrose 1959). Past research confirms that the management of important value-creating activities occurring at the subsidiary level, such as the transfer of knowledge and innovations, is crucial for the competitiveness of modern MNCs (Bartlett and Ghoshal 1989; Forsgren and Holm 2010; Hedlund 1986). However, several scholars propose that we still lack an understanding of to what extent and under what conditions the CHQ actually contributes to and add value to such activities (Ambos and Mahnke 2010; Chiabuschi et al. 2012a; Egelhoff 2010; Tallman and Koza 2010).

In the literature, two basic but rather contrasting roles or managerial approaches of the CHQ have been discussed. The first so called 'monitoring' role (cf. Foss 1997), emphasizes that main task of the CHQ is to work against opportunistic behavior (Williamson 1975) and to provide incentives toward common organizational goals. The dominant research has been on this monitoring role of the CHQ (see detailed analysis by Foss 1997) and the issue of whether the CHQ should use a hands-off strategy in terms of different means of supervision (cf. Alfoldi et al. 2012; Björkman et al. 2004). In contrast to this loss preventing role of the CHQ (e.g., Chandler 1991; Foss 1997), another stream of research emphasizes that the CHQ should have a more active and value adding role (Ambos and Mahnke 2010; Chandler 1991; Collis et al. 2007; Egelhoff 2010; Foss 1997; Foss et al. 2012). This would include responsibilities such as the facilitation of organizational learning and knowledge transfer, which implies the CHQ as an active participant in valuecreating processes at the subsidiary level (Forsgren and Holm 2010). Hence, a more recent stream of research emphasizes how an actual hands-on strategy by the CHQ is necessary (Goold and Campbell 2002; Goold et al. 1998) and suggests a more active involvement of the CHQ in subsidiary level activities (Ciabuschi et al. 2012b; Egelhoff 2010; Yamin et al. 2011).

There is little doubt in the literature that the CHQ is motivated to add value to the overall MNC network and is perceived as such by other units in the MNC (Anderson and Holm 2010; Ciabuschi et al. 2012a; Egelhoff 2010). However, recent research emphasizes the notion of the headquarters' 'knowledge situation' in network-like MNCs (cf. Forsgren and Holm 2010) in which the value added of the CHQ's managerial efforts has been questioned (Alfoldi et al. 2012). In the received literature on the network MNC it has been suggested that the CHQ has a limited access to relevant knowledge that are useful for subsidiary level activities. This implies that the CHQ is rather ill-informed (Foss et al. 2012) and consequently may suffer from behavioral liabilities such as an "outsidership" (Johanson and Vahlne 2009; Vahlne et al. 2012), a "radical uncertainty" about what it actually knows and what it needs to know (Forsgren and Holm 2010; Chiabuschi et al. 2011; Tsoukas 1996), and a liability of reliability (Verbeke and Greidanus 2009). Such managerial liabilities may give rise to managerial errors not only in terms of the implementation of badly designed supervision but also poorly developed value added participation 
(Forsgren and Holm 2010; Foss et al. 2012). Hence, from this perspective it can be expected that the opportunities for the CHQ to add value to innovation processes may be considerably constrained.

Due to CHQs lack of appropriate knowledge to involve themselves in transfer activities at the subsidiary level (Forsgren et al. 2005; Chiabushi et al. 2012b), it has been suggested that there is a need for research on how such liabilities may have an impact on such activities (cf. Foss et al. 2012). There has also been a call among International Business (IB) scholars for investigations to enhance our understanding about the particular circumstances under which the CHQ can add value to innovation transfer processes within MNCs (cf. Miao et al. 2016; Dellestrand and Kappen 2012). This paper contributes to these calls and enrich the literature by developing a framework that incorporates aspects of the 'knowledge situation' of CHQ to shed light on the value added role of CHQ management in innovation transfer processes, in particular under "sticky" transfer conditions.

Innovation transfer processes often become problematic and "sticky" due to the occurrence of a variety of transfer constraints (e.g., Simonin 1999). In this paper these constraints are categorized into three broad categories; knowledge-related constraints, contextual constraints, and resource-related constraints. Not only has much of the received research failed to simultaneously examine all of these antecedents, the role of the headquarters in transfer processes is lacking a deeper understanding (Chung 2014). Hence, the research question is: What is the value added role of CHQ monitoring and CHQ involvement in 'sticky' inter-subsidiary innovation transfer processes? For the simplicity of the paper, the value added of these two managerial approaches is viewed in terms of its' impact on the performance of the innovation transfer processes. A distinction is made between transfer efficiency and transfer effectiveness (Brown and Eisenhardt 1995; Ciabuschi et al. 2012b; Pérez-Nordtvedt et al. 2008, 2015). The transfer efficiency relates to the actual transfer process in terms of the costs and the speed of the process (cf. Szulanski 1996; Teece 1977; Zander and Kogut 1995), whereas the transfer effectiveness is related to the level of completion and the satisfaction of the transfer process (Kostova 1999; Kostova and Roth 2002).

The paper is organized as follows: the next section presents the conceptual framework and the relating hypotheses. First we present the issue of sticky transfer processes, after which we discuss the role of the CHQ and its knowledge situation in network MNCs. After that we develop a set of hypotheses on the value added of CHQ monitoring and CHQ involvement in transfer processes in situations where the transfer process is constrained by knowledge- contextual- and resource related barriers. The next section presents the method, including our research design, the data collection, the sample, and the operationalization of variables. In the following section we present the results of the OLS regression analysis. In the final section, a concluding discussion is presented including implications for management and future research. 


\section{Sticky Innovation Transfer Processes}

The literature on knowledge transfer varies in how knowledge transfer has been conceptualized. One stream of literature presents knowledge transfer as a linear, mechanical process in which knowledge is relocated and added to the knowledgebase of another actor (Kogut and Zander 1992; Spender 1996). Another stream of research puts emphasis on knowledge transfer as a highly complex and interactive process dependent on the beliefs, values and circumstances of the actors involved in this process (Nonaka 1994). Recently, considerable knowledge transfer research has adopted a source and a recipient model (Ko et al. 2014; Patriotta et al. 2013). From this perspective, knowledge transfer is viewed as a dyadic exchange between a source and a receiving unit involved in a transfer event. This is similar to Szulanski (1996, p. 28) stating that knowledge transfer is to be considered as "dyadic exchanges of organizational knowledge between a source and a recipient unit". In line with these views, we adopt the notion of knowledge transfer as a transfer process that takes place between senders and receivers within an MNC. The paper is specifically concerned with inter-subsidiary knowledge transfer where a subsidiary (the sender) transfers an innovation developed by the subsidiary to another subsidiary (the receiver) within the MNC. The transfer is thus viewed as a dyadic, targeted and deliberate process between a source and a receiving unit involved in a transfer event (Patriotta et al. 2013). Furthermore, the transfer process involves transfer of subsidiary generated innovations, where 'innovation' implies the result of the technological development by a firm or as a result of the combination of the firm's existing technologies and know-how in a novel way (Teece 1986). Hence, in this study innovation transfer is viewed as a specific knowledge transfer process. In the following, knowledge transfer and innovation transfer will be used interchangeably.

In general, knowledge transfer processes are often viewed as "sticky" simply because they often encounter a number of different constraints, e.g., barriers, and knowledge is therefore not readily or easily transferred (Szulanski 2003). Past research has covered several constraining conditions to knowledge transfer which has been categorized into the following categories; knowledge-related constraints, contextual constraints, and resource-related constraints. The knowledge related constraints refer to the nature, attributes, and complexity of the knowledge itself (Grant 1996a; Hansen 1999; Spender 1996; Szulanski 1996, 2000; Winter 1987; Zander and Kogut 1995). For instance, the nature of knowledge, such as the inherent level of tacitness, specificity, and complexity, are factors that result in knowledge ambiguity (Reed and DeFillipi 1990; Simonin 1999; van Wijk et al. 2008). Knowledge ambiguity concerns the uncertainty of what the underlying knowledge components are and how they interact. It has been argued that learning about the "specifics of the knowledge source takes time and constrains the ultimate success of the transfer process" (van Wijk et al. 2008, p. 833). Furthermore several studies provide evidence that knowledge ambiguity constrains transfer processes (Levin and Cross 2004; Persson 2006; Szulanski et al. 2004) and is directly and negatively related to knowledge flow performance (Simonin 1999). 
The contextual constraints refer to problems related to the situation in which the transfer occurs (Simonin 1999; Szulanski 1996). According to Postrel (2002) knowledge inputs are embedded in a cognitive, behavioral, or organizational context. This context not only constrains the actual transfer process but also the usefulness of the knowledge in different situations (van Wijk et al. 2008). The contextual barriers include technical and organizational differences (Allen 1977; Cohen and Levinthal 1990; Szulanski 1996) as well as more cognitive aspects such as the cognitive resistance by the recipients to accept external knowledge (Katz and Allen 1982; Lichtenthaler and Ernst 2006) or the resistance by the receivers to engage in transfer due to potential loss of advantage within the MNC (e.g., the notinvented-here syndrome). Resource-related constraints are to a large extent connected to the tangible time, resources and efforts that can be put into the transfer process (Lin et al. 2008). For instance, due to the lack of human as well as financial resources to put into the process, both the sending and the receiving units may face difficulties in engaging in the transfer process (Szulanski 1996; Forsgren 1997). The difficulties may rise both in terms of poor communication and relational exchanges (Collins and Hitt 2006).

From the above established research it can be concluded that these conditions create 'sticky' innovation transfer environments and have, in general, a restraining effect on the overall innovation transfer processes (Persson 2006; Kang 2013). Due to the extensive literature supporting a negative direct effect of the above mentioned transfer constraints on knowledge transfer process in general, we will not elaborate further on the direct effect of these transfer constraints on innovation transfer processes.

\subsection{The Value Added of CHQ in Innovation Transfer Processes- A Network Approach}

On an overarching level, the role of the CHQ has been described in terms of two basic managerial approaches. Within the first one, the role of headquarters is 'avoiding the negative' (Foss 1997). This role implies the prevention of losses by the use of monitoring (Williamson 1975). In line with transaction cost theory it is asserted that $\mathrm{CHQ}$ can monitor and thus control other units in order to reduce opportunistic behavior and to ensure the most efficient use of scarce resources (Chandler 1962; Williamson 1985). A similar argument stems from agency theory emphasizing that managers are self-serving and that monitoring and incentive mechanisms can bring about goal equilibrium between CHQ and their dispersed subsidiaries (Jensen and Meekling 1976; O'Donnell 2000). Hence, this view on the role of the CHQ is based on the view of a 'solver of agency problems' (Foss 1997) and constitutes a manifestation of headquarters power that have a tendency to constrain the subsidiaries' behavior (Ambos and Mahnke 2010). Overall, this perspective suggests that barriers can easily be overcome through the exercise of hierarchical control and minimal corporate involvement (Roth et al. 1991).

In contrast, the network perspective represents a shift in the view of the role of CHQ from a supervisor to an organizer of learning and knowledge sharing within and across units. A network MNC is characterized by a low degree of formalization, 
extensive knowledge transfer and resource-rich and powerful subsidiaries (Foss et al. 2012; Forsgren et al. 2005). Research on the role of the CHQ within the network tradition has resulted in the development of concepts such as corporate parenting (Goold et al. 1998; Goold and Campbell 2002), headquarters attention (Bouquet and Birkinshaw 2008; Rugman and Verbeke 2001; Ambos and Mahnke 2010), and headquarters involvement (Ciabuschi et al. 2011, 2012b; Forsgren and Holm 2010; Raab et al. 2014; Yamin et al. 2011). Within this stream of research an active involvement of the headquarters is emphasized in terms of investments in time, effort and resources in unit-level activities (Bouquet and Birkinshaw 2008), and a value-adding nature of corporate parenting (Goold et al. 1998; Egelhoff 2010). For instance, literature dealing with parenting theory (cf. Goold et al. 1998; Goold and Campbell 2002) suggests that there is a high likelihood of headquarters involvement in subsidiary level activities and that such involvement leads to an enhanced outcome of these processes. However, other network scholars propose that actors in general have limited knowledge, limited control over resources and cannot fully overview the behavior, intentions, and interactive processes of other actors (Forsgren et al. 2005). Consequently, it is suggested that the CHQ's knowledge situation in the network MNC is reflected by an increasing complexity which may result in managerial liabilities such as outsidership (Johanson and Vahlne 2009; Vahlne et al. 2012), a liability of uncertainty (Ciabuschi et al. 2011, 2012b; Forsgren and Holm 2010), and a liability of reliability (Verbeke and Greidanus 2009).

As for the liability of outsidership (Johanson and Vahlne 2009), this refers to the CHQ's lack of understanding of the subsidiaries' local networks and contexts. It is not until the headquarters is an 'insider', as the learning, trust and commitment building can take place (Johanson and Vahlne 2009). Vahlne et al. (2012, p. 229) argue that headquarter managers that face local contexts of which they have little or no information "have to manage under a cloud of uncertainty and thus in an atmosphere of goal ambiguity". This situation may become even more complicated when the CHQ suffers from a liability of uncertainty (Ciabuschi et al. 2011; Forsgren and Holm 2010; Foss et al. 2012; Vahlne et al. 2012) regarding the level, relevance and usefulness of the knowledge it possesses about the subsidiaries and their contexts in which the innovation processes take place. From an uncertainty point of view (cf. Hayek 1945; Kirzner 1982), the key to achieving coordinated transfer activities does not depend on "those 'higher up' collecting more and more knowledge" (Tsoukas 1996, p. 22), but on knowing what to collect and how and where to collect it (Andersson et al. 2007; Barner-Rasmussen et al. 2010). In line with this argument, research proposes the idea and concept of "bounded reliability" (Verbeke and Greidanus 2009) suggesting that losses in efficiency and effectiveness can be related to factors such as 'intentional deceit' and 'over-commitment'. This liability of reliability implies that $\mathrm{CHQ}$ often tend to make false or even break promises about their commitment or make commitments based on impulsivity, i.e., without any deeper knowledge or insight (Verbeke and Greidanus 2009). This may result in an overconfidence of its own role in a process or activity, rather than the possession of accurate and reliable knowledge. Based on the above reasoning, there is a high likelihood that subsidiaries perceive CHQ management as a bad cause (Foss et al. 2012). 
The value added role of these two managerial approaches, e.g., CHQ monitoring and CHQ involvement, is viewed in terms of its' impact on the actual performance of the transfer process. In much of the research on knowledge transfer, the emphasis has been put on the flow of knowledge in terms of the occurrence, frequency or degree of knowledge exchange rather than the actual performance, e.g., the success of the transfer process. When knowledge transfer is seen as 'successful', it involves a cheap, fast and complete transfer process which also adds to the overall satisfaction (Inkpen 2000; Szulanski 1996). It is claimed that although the transfer process is fast, if the knowledge is not perceived by the recipient as particularly relevant or easy to understand, the transfer will not result in the desired outcomes (PérezNordtvedt et al. 2008). This is in line with scholars arguing that there is a need to view the actual performance outcomes of transfer processes in terms of the efficiency and the effectiveness of the knowledge transfer process (Yamin et al. 2011). Transfer efficiency relates to the cost and the speed of the actual transfer project (cf. Pérez-Nordtvedt et al. 2008; Teece 1977; Zander and Kogut 1995; Zahra et al. 2000). The transfer effectiveness is related to the level of completion of a transfer project and to what extent it is used and implemented at the receiving unit (Ambos and Ambos 2009; Kostova and Roth 2002; Raab et al. 2014). This is similar to the distinction made by Daft (1998, p. 663), where he defines efficiency as "the amount of resources used to produce a unit of output" (e.g., time and cost) and effectiveness as "the degree to which goals are attained" (i.e., to what extent the innovation is actually implemented within the $\mathrm{MNC}$ ). Hence, in line with the above distinction of innovation transfer performance, the value added of 'CHQ monitoring' and 'CHQ involvement' is considered to be reflected in the extent to which these two managerial approaches contribute to innovation transfer effectiveness and efficiency.

\subsection{CHQ Monitoring in Sticky Transfer Environments}

It has been argued that the ability of the CHQ to use hierarchy decreases in networklike organizations (Forsgren et al. 2005). Furthermore, the opportunities for the CHQ to add value to innovation processes at the subsidiary level through monitoring are severely constrained in a situation of radical uncertainty (Forsgren and Holm 2010). The reason for this is that the CHQ in network MNCs are often illinformed due to 'sheer ignorance' (Ciabuschi et al. 2011), which will give rise to managerial errors in decision making (cf. Foss et al. 2012).

When transfer processes are constrained by high ambiguity of the inherent knowledge components of the innovation, the extent to which the CHQ can add value to these processes is highly dependent on its ability to provide relevant expertise, equipment and facilities to overcome this knowledge ambiguity. If the CHQ uses monitoring, where the CHQ imposes a distant role as an 'outsider' in relation to the transfer processes, it may find it hard to identify the sources of the knowledge ambiguity faced by the participating subsidiaries. In other words, the 
CHQ may have difficulty in estimating ex ante what knowledge is needed to overcome the knowledge ambiguity. When the knowledge provided by the CHQ is perceived as limited in terms of its relevance and usefulness, this may only lead to confusion and demotivation may slow down the transfer process. Furthermore, if the corporate parent only contributes to local subsidiary activities from a distance, it only operates in 'alien territory' (Campbell et al. 1995) and the subsidiaries may face a lack of leadership and guidance regarding the focal innovation which will put constraints on the overall satisfaction with the process.

Hypothesis 1 $a-b$ : The effect of knowledge ambiguity on (a) innovation transfer efficiency and $(b)$ innovation transfer effectiveness is negatively moderated by CHQ monitoring.

During transfer processes, contextual constraints often arise due to e.g., technical or organizational differences (Allen 1977; Cohen and Levinthal 1990; Szulanski 1996) as well as cognitive resistance among the senders and recipients. In such circumstances, a high level of corporate involvement has been proposed to be necessary (Chiabuschi et al. 2012b). However, the CHQ's ability to add value to the local subsidiaries' innovation transfer processes requires both knowledge and understanding of the subsidiaries' local contexts (cf. Campbell et al. 1995; Forsgren and Holm 2010). Being an outsider (e.g., Johanson and Vahlne 2009), the CHQ's suffer from a lack of knowledge about the subsidiary context and the knowledge controlled by the subsidiary. In line with this, research suggests that if knowledge transfer originates within a context of confusion it will hamper the ability of the involved participants to improve performance (Ambos and Ambos 2007). This implies that, without being at least somewhat connected to the local subsidiaries' transfer activities and aware of their contextual differences, CHQ monitoring cannot provide any potential benefits to local subsidiary transfer activities, neither in regard to the speed and cost of the innovation transfer process, nor for the overall satisfaction and the implementation of the innovation transfer process.

Hypothesis 2a-b: The effect of contextual constraints on (a) innovation transfer efficiency and (b) innovation transfer effectiveness is negatively moderated by $\mathrm{CHQ}$ monitoring.

If the innovation transfer process is constrained by the lack of relevant resources to put into the specific transfer process, the CHQ may have a problem in identifying where and the extent to which there is a resource deficit when acting as an outsider to the process. This means that CHQ monitoring in terms of the mere provision of incentive-based systems (Minbaeva et al. 2003) may only be a signal that the CHQ does not want to be involved due to the lack of knowledge about or interest in the transfer project. In addition, by not being directly involved in the transfer project, any resource allocation effort 'from a distance' may only be arduous and wasteful and done for the wrong reason. Hence, based on the view of the CHQ as an outsider, suffering from a liability of uncertainty, we could expect that the use of CHQ monitoring in situations where the participating subsidiaries face resource deficits 
will only prolong the innovation transfer process and give rise to increased costs and a dissatisfaction of the transfer and implementation process.

Hypothesis 3a-b: The effect of resource constraints on (a) innovation transfer efficiency and (b) innovation transfer effectiveness is negatively moderated by CHQ monitoring.

\subsection{CHQ Involvement in Sticky Transfer Environments}

From a radical uncertainty view, the CHQ has, even as an insider, a limited ability to know what information to collect, where to collect it and what role they should play within the process. According to Ambos et al. (2006) and Schulz (2001), the 'quantity' of knowledge flows is not nearly as important as the 'quality' of the knowledge transferred. This means that the value added of CHQ management of subsidiary activities depends on the quality and timing of received know-how and expertise. Hence, if the CHQ lacks relevant and useful knowledge of the nature and complexity of the knowledge elements that constitutes the particular innovation, or even worse, is ignorant about its lack of knowledge (Chiabuschi et al. 2011), the subsidiaries involved in the transfer process have to adapt to the CHQ's lack of relevant knowledge instead of being able to rely on it. The knowledge and support received will therefore be of rather poor quality. Under such circumstance, the headquarters involvement in subsidiary activities may only demotivate the subsidiaries participating in the transfer, "even if such intervention is entirely benevolent in its intentions" (Foss et al. 2012, p. 248). Such misguided benevolence and over-commitment can only be harmful (Verbeke and Greidanus 2009) and result in less effective implementation efforts and dissatisfaction of the innovation transfer process. It may also require an increase in information gathering activities among the participating subsidiaries, which ultimately would be very costly and time consuming. Consequently, the following two hypotheses can be formulated:

Hypothesis 4a-b: The effect of knowledge ambiguity on (a) innovation transfer efficiency and (b) innovation transfer effectiveness is negatively moderated by CHQ involvement.

The 'liability of uncertainty' of the subsidiary context further suggests that there is a cognitive disconnection between the CHQ and the subsidiary managers' perceptions. As stated by Foss et al. (2012, p. 252), where there are contextual contingencies that are problematic, then "supplying the extra intelligent effort that may be required" becomes difficult. In network MNCs, the involvement by the CHQ may turn into harmful intervention if it does not understand these contingencies and is not able to provide useful and reliable knowledge and support (Foss et al. 2012). This may lead to an increase in transfer costs and could compromise the actual outcome of the innovation transfer process. This is in line with Verbeke and Greidanus (2009, p. 14) suggesting that failed commitments may stem from contextual misconceptions of corporate managers as a result of an 
overconfidence of its own role in the process, rather than the possession of reliable knowledge. Hence, if the transfer process is constrained by, for instance, cognitive or organizational differences between the sending and receiving units, CHQ involvement may therefore harm rather than add value to the process. This could result in a loss in motivation and work effort among the participating units. Based on this reasoning, we expect that:

Hypothesis 5a-b: The effect of contextual constraints on (a) innovation transfer efficiency and (b) innovation transfer effectiveness is negatively moderated by $\mathrm{CHQ}$ involvement.

When the process is constrained by an explicit resource scarcity, a more hands-on approach in terms of an active intervention and support would imply that the CHQ will be able to actively provide the participating subsidiaries with time and resources. It has been argued that the CHQ, by being an "insider" in the process, is in a position to allocate the right resources at the right time, despite its lack of knowledge and understanding of the transfer context (cf. Dellestrand and Kappen 2012; Miao et al. 2016). Even though the CHQ as an outsider acts under a cloud of uncertainty (e.g., Vahlne et al. 2012), that is act under situations of which they have little or no information, it can be expected that the impact of such uncertainty is less pronounced in situations where a lack of resources is the main barrier to successful transfer. Hence, in a resource-constrained transfer environment, ceteris paribus, CHQ involvement will add value to the transfer process by an active involvement in terms of actual time, effort and resources spent on the specific transfer project. This will subsequently improve not only the speed and cost of the transfer process but also the actual implementation and satisfaction of the innovation transfer process.

Hypothesis $6 a-b$ : The effect of resource constraints on (a) innovation transfer efficiency and $(b)$ innovation transfer effectiveness is positively moderated by $\mathrm{CHQ}$ involvement.

Our research model, shown in Fig. 1 proposes an integrated model and presents the individual constructs, the inter-relatedness between the different constructs, and the developed hypotheses of the study.

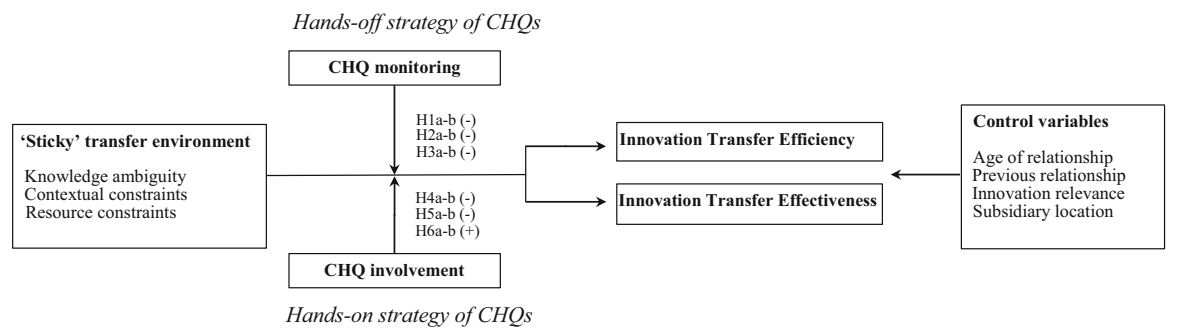

Fig. 1 Research model 


\section{Research Method}

\subsection{Data Sample}

The data was collected in conjunction with a larger research project on the development and transfer of innovations in MNCs (cf. Ciabuschi 2004; Persson 2006; Kang 2013). The research focus of the project was on innovation processes (i.e., innovation development and transfer processes). The unit of analysis for this paper is lateral transfer projects, where each project is the transfer of a specific innovation of a source subsidiary to a recipient subsidiary within the same MNC.

The data was collected using a two-stage sampling procedure. In the first stage we selected a total of $25 \mathrm{MNCs}$ heavily engaged in technology development. The sampling procedure started by approaching large MNCs with a global presence that conducted innovation development and innovation transfer projects. Initially, a formal letter was sent to the companies asking them to participate in the study. After an initial presentation of the project and having obtained access to the companies, a first meeting was held at the CHQ with purpose of getting acquainted with the organization and to request for potential respondents at the subsidiary level. Thereafter the screening process of which innovations that would be suitable for the study was initiated. Meetings were then arranged with the corporate managers, the divisional headquarter managers and senior management teams to identify possible innovations. The next step was to visit the subsidiaries and key units involved in developing the identified innovations. During this stage, we got access to subsidiary level managers and engineers involved in the identified innovation development and transfer processes. For practical reasons we requested to investigate maximum of three innovation transfer projects for each participating MNCs. Three basic selection criteria were used when selecting innovation projects: the innovations should be important to the company, have been completed no later than 10 years ago, and have been transferred to other units within the MNC. After the innovation projects were identified, the source subsidiary managers and/or engineers that were involved in the transfer process were selected as the respondents for the questionnaire.

The final sample contained a total of 186 dyadic transfer projects in 25 participating MNCs in different manufacturing industries, e.g., paper and pulp, machinery and equipment, electrical machinery and motor vehicles, relating to 87 different innovations. A total of 65 subsidiaries were investigated, located in 15 countries in Asia, Europe and North America. Each subsidiary had developed on average 1.2 innovations and the average subsidiary size, in terms of the number of employees, was 630 with average annual sales of 270 million euros.

\subsection{Data Collection}

The data was collected between 2002 and 2009, by visiting subsidiaries located in 15 countries. The data collection was carried out using a standardized questionnaire administered through face-to-face interviews with R\&D managers and engineers at the sending subsidiaries. These subsidiaries were involved in both the development 
and the transfer process of the focal innovation. In order to avoid ambiguous questions and to enhance the applicability of indicators, the questionnaire was pre-tested through two independent pilot interviews with MNC managers and a group of executive MBA students. Since the scope of the standardized questionnaire was extensive, encompassing several aspects of the innovation development and transfer process, sending out the questionnaire by e-mail was deemed unfeasible. Instead, data for each innovation were collected through face-to-face interviews conducted at the subsidiary that had developed the innovation. The duration of the interviews was between 2 and $4 \mathrm{~h}$. Sometimes the interviews were followed by visits to the facilities and practical demonstrations of the innovation in question. In most cases several respondents took part in the interviews (e.g., subsidiary top managers, R\&D managers and/or engineers). This implies that we use multiple respondents since each of these subsidiary respondents individually answered the questionnaire. An advantage with this face-to-face approach is that it allows the interviewer to have greater control over the questionnaire survey. In addition it ensures that the information is received from a knowledgeable person, and increases the possibility to clarify questions, as well as to detect inconsistencies in the answers. Consequently, this research method offers the advantage of providing high quality data, by reducing the missing data for individual questions to a minimum and ensuring that the objectives for the questions are met (cf. Fowler 1993). A consequence of this approach is that we only have information from key respondents at the "sending" subsidiaries.

\subsection{Variables and Measures}

\subsubsection{Dependent Variables}

In this paper we investigate the extent to which CHQ management can add value to the subsidiary-level transfer processes. The value added role of CHQ management is measured as the impact on the innovation transfer performance of the particular innovation projects studied. For the innovation transfer performance, we made a distinction between transfer efficiency and transfer effectiveness. This distinction has been used by Pérez-Nordtvedt et al. (2008), where they claim that both efficiency and effectiveness are needed to understand knowledge transfer performance and that these two dimensions reflect different aspects of knowledge transfer performance. The first dependent variable transfer efficiency relates to the speed and cost of the transfer project between the sender subsidiaries and the recipient subsidiaries. This concept is based on Daft (1998) and Pérez-Nordtvedt et al. (2008), where efficiency is defined as the amount of resources used in terms of speed and economy. The variable consists of four items. The respondents were asked (1) to what extent the counterparts have received the innovation very quickly, (2) if the starting point of the innovation transfer was much earlier than expected, (3) if the first day of innovation used by the receiver was much earlier than expected and (4) if the actual costs of innovation transfer were much lower than expected (reverse coded). All items were measured using a seven-point scale (where $1=$ totally disagree and $7=$ totally agree). We used the average value of the items for this variable (Cronbach's alpha was 0.75 ). The questions measuring the speed are based 
on Zander and Kogut (1995) and Zahra et al. (2000). The question covering cost is based on the work of Teece (1977), Szulanski (1996) and Hansen et al. (2005). In the studies of Ciabuschi et al. (2011) and Yamin et al. (2011) similar measurements to cover both speed and costs has been used.

The second dependent variable transfer effectiveness refers to the level of transfer completion; innovation adaptation (in terms of the innovation was easily used by the receiving unit); and the extent to the satisfaction of innovation transfer process. Daft (1998) and Pérez-Nordtvedt et al. (2008) define effectiveness as the degree to which goals are attained in terms of 'comprehension and usefulness'. In line with this definition, we use three indicators to capture the level of completion, adoption and satisfaction with the transfer process. We asked the respondents to assess the extent (1) of completed innovation transfer, (2) to which the innovation has been very easy to adopt by this counterpart and (3) to which the performance the innovation transfer process was very satisfactory. The items were measured using a seven-point scale (where $1=$ totally disagree and $7=$ totally agree) and we used the average value of these three items (Cronbach's alpha was 0.73). The questions regarding the level of completion and a satisfactory transfer outcome is based on Daft (1998). The term easy adoption is based on Lane and Lubatkin (1998), Lord and Ranft (2000) and Simonin (1999) where easy adoption captures the usefulness of the transferred knowledge and thus a measure of effective transfer processes (Yamin et al. 2011).

\subsubsection{Independent Variables}

The three independent variables are knowledge ambiguity, contextual constraints, and resource constraints. These variables capture different aspects of 'sticky' transfer environments. The variable knowledge ambiguity covers the inherent tacitness, complexity and specificity of the knowledge contained in the innovation itself. Winter (1987), Bresman et al. (1999) and Zander and Kogut (1995) delineate knowledge ambiguity in terms of the relative articulability and codifiability of knowledge. Knowledge ambiguity can be captured by the newness and variety of the interdependent skills and assets that are linked to a particular knowledge (Reed and DeFillippi 1990) such as different interdependent technologies, routines, individuals, and resources (Simonin 1999); or transaction of specific skills and assets that are utilized in production processes; or in the provision of services (Simonin 1999). Accordingly, we asked the respondents to assess the extent to which the transferred innovation comprises (1) technology that is new to your unit, (2) a high variety of knowledge bases (e.g., chemistry, physics and engineering). The respondents was also asked if, to develop the innovation technology/process know-how, they had to invest significantly in (3) specialized equipment and facilities and (4) skilled human resources (Cronbach's alpha was 0.72).

The variable contextual constraints covers differences in the cognitive and organizational characteristics among the sending- and the recipient units. The respondents were asked to evaluate to what extent (1) your unit hesitates to transfer the innovation as you will lose your advantage within the MNC, (2) the counterpart hesitates to receive the innovation as it was not invented by them, (3) technical differences makes transfer problematic, and (4) organizational differences makes 
transfer problematic (Cronbach's alpha was 0.73). The first two questions relate to cognitive barriers and has been used by Katz and Allen (1982) and Lichtenthaler and Ernst (2006). The questions three and four relates to the organizational context and have been used by Allen (1977) and Szulanski (1996) in their research on organizational barriers in knowledge transfer processes.

The third independent variable resource constraints, is intended to capture difficulties in terms of the availability of necessary time and resources to put into the particular transfer project (cf. Lin et al. 2008). As argued in Minbaeva and Michailova (2004), the ability to transfer knowledge is contingent on the access to necessary resources. The necessary resources may vary in different organizations and relates to various aspects such as time, human resources, financial resources, and up-to-date information system (cf. Szulanski 1996). We asked the respondents to assess if (1) the lack of necessary resources (efforts, time and resources) within your unit to put in the specific transfer relationship makes the transfer difficult, and if (2) the lack of necessary resources (efforts, time and resources) in the counterpart to put in this specific relationship makes the transfer difficult (Cronbach's alpha was 0.71).

\subsubsection{Moderating Variables}

In order to investigate the value added role of CHQ management of innovation transfer processes, two moderating variables were developed. The first variable, CHQ monitoring captures a hands-off CHQ strategy and the focus of the traditional incentive-creating function of CHQ (cf. Chandler 1991). Accordingly, the respondents were asked to evaluate the extent to which (1) financial bonuses are given to individuals for sharing knowledge, (2) individuals with the reputation for sharing knowledge are favored for promotion, and (3) employees are fully aware of that bonuses may be received for knowledge sharing (Cronbach's alpha was 0.73). Similar measurements have been used in studies by Balkin and Gomez-Mejia (1987), Galbraith and Merrill (1991) and Fey and Furu (2008).

The second variable, the $C H Q$ involvement reflects a more 'hands-on' CHQ strategy. Based on the suggestion by Forsgren and Holm (2010), this role reflects the CHQ involvement in and contribution to the performance of value-creating processes at the subsidiary level. The variable intends to capture the level of attention to, direction of, and participation in the transfer process by the CHQ. A similar approach has been used by Ciabuschi et al. (2011), Dellestrand and Kappen (2012) and Yamin et al. (2011). We thus asked the respondents to assess the extent to which the CHQ (1) has instructed you to share this innovation with the counterpart, (2) has been heavily involved in conducting the actual transfer process with the counterpart, (3) has taken the complete responsibility for the transfer of this innovation to this counterpart, and (4) with regard to transfer of the innovation, to what extent is this driven by the requirements from CHQ (Cronbach's alpha was 0.69; MIC value was 0.37).

\subsubsection{Control Variables}

Some control variables that can influence the performance of knowledge transfer efficiency and effectiveness are included in this study. The first control variable is age 
of relationship between the sender and the recipient unit and how this can affect the performance of transfer process. Successful innovation transfers will be more likely when it takes place between older and more established relationships (Fey and Furu 2008). Hence, we asked the respondents to assess the age of the relationship between their unit and the unit/business area that received the innovation. The second control variable captures the level of previous relationship between the sending and receiving units. A shared history and routines of jointly utilizing transferred knowledge will lead to shared meanings and behaviors, which in turn will facilitate coordination of the transfer activities by making counterpart's behaviors more understandable, predictable and stable (March and Simon 1958; Nelson and Winter 1982; Szulanski 1996). The level of previous relationship will thus ease the transfer process by making it more institutionalized and routinized, thus affecting the transfer performance in terms of efficiency and effectiveness. The variable is measured by asking the respondents to assess their general relationship with the receiving unit in terms of (1) the level of previous cooperation; (2) the extent of previous shared knowledge; and (3) the extent of existing transfer routines (Cronbach's alpha was 0.72).

We also test for the relevance of the innovation. The relevance of knowledge is discussed in Grant (1996b) as an important condition for acquiring returns from the knowledge. The relevance of the knowledge for an organization makes the knowledge valuable (Schulz 2003). It has been shown (Björkman et al. 2004) that the perceived strategic importance of knowledge by the CHQ as well as the MNC units have a positive impact on the knowledge transfer processes. The relevance of innovation is therefore likely to facilitate the innovation transfer process and make transfer process more efficient and effective. Hence, the respondents were asked to assess the importance of the focal innovation (1) to your unit; (2) to the division/business area as a whole; and (3) to the MNC as a whole (Cronbach's alpha was 0.76).

Lastly, we tested for the spatial distance between the sending and the receiving units. The control variable subsidiary location tries to capture different dimensions of distance between these units in terms of the geographic distance as well as cultural and linguistic distance (cf. Ambos and Ambos 2009). Such dimensions of distance could lead to an increase in cost, communication difficulties, and resource allocation complexity, thus reducing the efficiency and effectiveness of innovation transfers (Baaij and Slangen 2013; Dellenstrand and Kappen 2012). The most noticeable difference would occur between Western and Eastern (Asian) subsidiaries, since the geographical, cultural and linguistic differences would be most prevalent (Ambos and Ambos 2009). This distinction of Western and Eastern subsidiaries has been used in other recent studies (cf. Bhagat et al. 2002). Hence, we identified the respondents (e.g., the sending units) country of location and also asked them about the geographical location of their receiving units. We then created a dummy variable to control for whether the innovation transfer occurred between Western to Asian subsidiaries (coded as 1), or among Western (European and/or North American) to Western subsidiaries (coded as 0). More details about the operationalization and construct reliability are shown in the "Appendix".

All the included variables show a high inter-item reliability with Cronbach's alpha above the recommended threshold value of 0.70 (Hair et al. 2006), except for the variable CHQ active managerial function (Cronbach's alpha 0.69). However 
when there are a small number of items in the scale (fewer than ten), the mean interitem correlation (MIC) value can be used to further support the reliability of the items. Optimal MIC values range from 0.2 to 0.4 (recommended by Briggs and Cheek 1986). The MIC value for the variable CHQ involvement was 0.37 which is within the rage of optimal MIC values. To examine the extent of common method bias in our data, a Harman's one factor test was conducted (Podsakoff and Organ 1986). The results of the principal components factor analysis revealed eleven factors with eigenvalues greater than 1.0 that together accounted for $82.4 \%$ of the total variance explained. Together with multiple factors and the relatively low amount of total variance explained by the first two factors (20.9 and $11.1 \%$ respectively) indicates that common method bias should not be a significant problem for analysis of the data (Podsakoff and Organ 1986). We also reduced this risk of common method bias through the design of the data collection process, where the answers were gathered from multiple respondents that were involved in either the innovation development or transfer process for a particular innovation.

\section{Results}

The hypotheses were tested using OLS regression. Here we use the basic multi-attribute measurement model represented by Fishbein's (1963) equation. Table 1 presents some descriptive statistics and the correlation matrix of the variables used in the regression analysis. Some significant correlations may exist between variables, but, since a rule of thumb is above 0.7 (cf. Hair et al. 2006) none of the correlations were high enough to indicate any problems with multicollinearity in the data. To check for further multicollinearity, especially for the moderating variables, the variance inflation factor (VIF-values) were calculated. A common cut-off threshold corresponds to a VIF-value below 10 (cf. Hair et al. 2006, p. 230), and since there were no VIF values greater than 2.61(where one variable showed 2.61 and another 2.39 all others below 2) multicollinearity does not appear to pose any severe problems in the analysis. In addition, a check for normal distribution was done through performing a KolmogorovSmirnov test. This revealed a significance of all variables greater than 0.06 (where less than 0.05 will have tendencies of non-normality). We also carried out normal probability plots which showed that all the variables were normally distributed.

Table 2 presents the results of the multiple regression analysis. The test for the control variables are shown in model 1 and model 4. In model 1 none of the control variables were significantly related to innovation transfer efficiency ( $F$ value 0.47 and adjusted $\mathrm{R}^{2}-0.03$ ). This is similar to recent studies that provide evidence of that previous engagements and collaboration between sending and receiving units do not speed up current work effort as could be expected (Dellestrand and Kappen 2012). In Model 4 it is revealed that of the control variables, only the 'previous relationship' has a significant positive effect on transfer effectiveness. There is also a tentative direct relationship between the 'subsidiary location' and innovation transfer effectiveness ( $\mathrm{F}$ value 1.66 and adjusted $\mathrm{R}^{2} 0.04$ ).

The independent variables and the moderating variables were included in Model

2 (transfer efficiency) and Model 5 (transfer effectiveness). Model 2 reveals a 


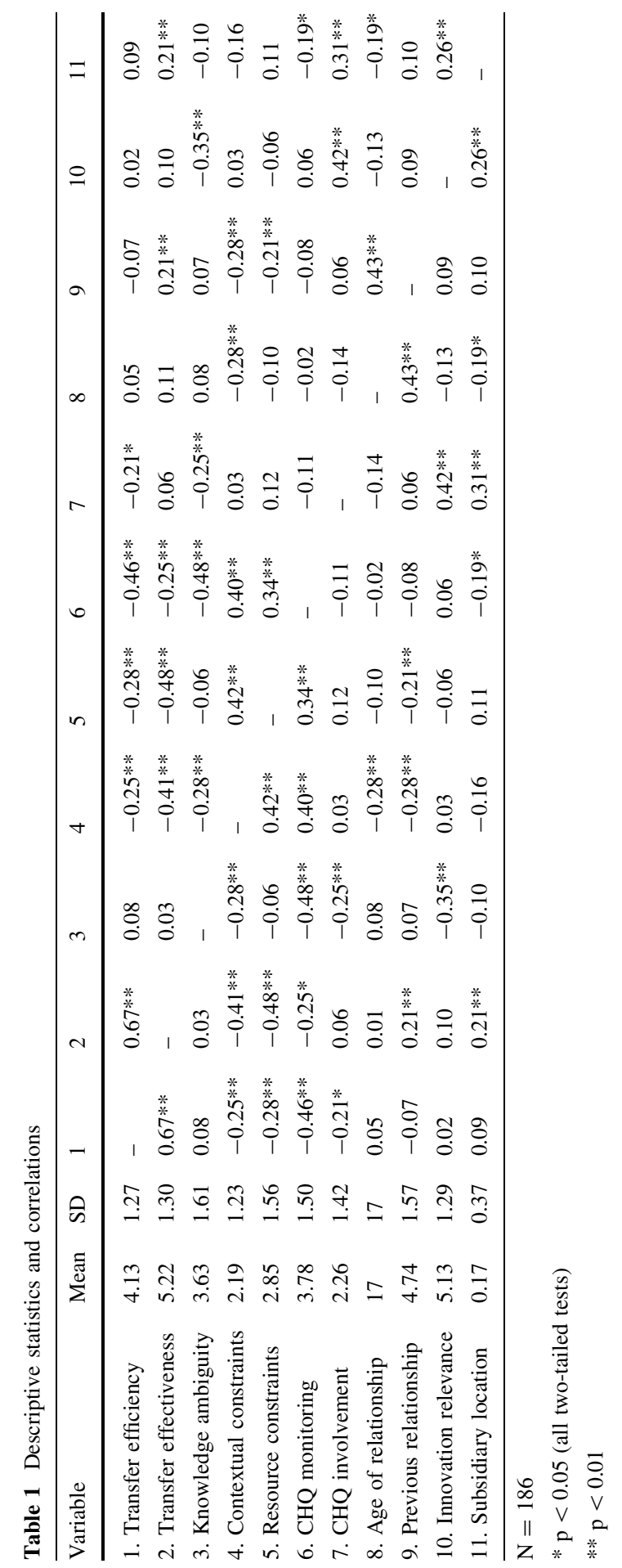




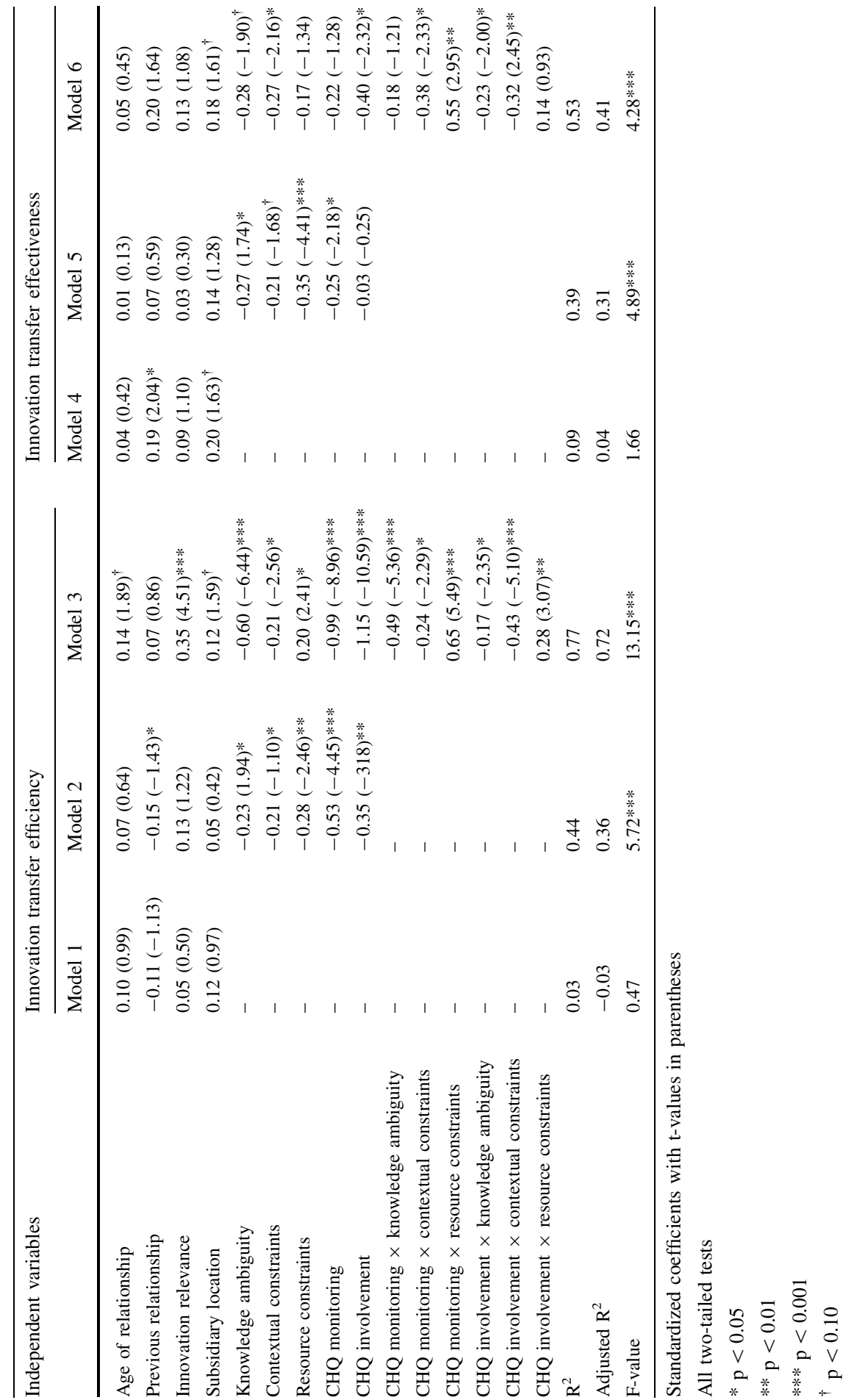


significant $\mathrm{F}$ value of $5.72(\mathrm{p}<0.001)$ and an adjusted $\mathrm{R}^{2}$ of 0.36 . Model 2 reveals that there is a direct and significant negative effect of all the independent variables on innovation transfer efficiency. Hence, these three independent variables are thus constraining the efficiency of innovation transfer. It also shows that there is a direct and significant negative effect of the two moderating variables on innovation transfer efficiency. In Model 5 the independent variables and the moderating variables were included for transfer effectiveness. The model shows a significant $\mathrm{F}$ value of $4.89(\mathrm{p}<0.001)$ and an adjusted $\mathrm{R}^{2}$ of 0.31 . The results reveal that knowledge ambiguity and resource constraints are directly and negatively related to innovation transfer effectiveness. There is a tentative and direct negative impact of contextual constraints on innovation transfer effectiveness. Model 5 also show that CHQ monitoring is direct and negatively related to innovation transfer effectiveness whereas there is a negative but not significant direct effect of CHQ involvement on transfer effectiveness.

The findings of the hypotheses testing are found in Model 3 (transfer efficiency) and Model 6 (transfer effectiveness) in which the moderating (interaction) variables 'CHQ monitoring' and 'CHQ involvement' are included. Model 3 shows a significant $F$ value of $13.15(\mathrm{p}<0.001)$ and an adjusted $\mathrm{R}^{2}$ of 0.72 . Model 6 reveals a significant $F$ value of $4.28(\mathrm{p}<0.001)$ and an adjusted $R^{2}$ of 0.41 . A suggested by Aitken and West (1991), all the independent were standardized before we conducted the test of the moderating effects of CHQ monitoring and CHQ involvement (e.g., an interaction effect test). The moderating effect is provided by testing the effect of the interaction between CHQ monitoring and CHQ involvement and the independent variables on transfer efficiency and effectiveness.

In Model 3 it is shown that the effect of knowledge ambiguity on transfer efficiency is negatively moderated by CHQ monitoring. Similarly, we find that the effect of knowledge ambiguity on transfer effectiveness is negatively but not significantly moderated by $\mathrm{CHQ}$ monitoring. Accordingly, this gives support for hypotheses 1a (see Model 3) but 1b is not supported (see Model 6). The results also reveal that the effect of contextual constraints on transfer efficiency and on transfer effectiveness is negatively moderated by CHQ monitoring. This lends support for hypotheses 2a (see Model 3) and 2b respectively (see Model 6). Contrary to our expectations, Model 3 and Model 6 reveal that the effect of resource constraints on transfer efficiency as well as on transfer effectiveness is positively moderated by CHQ monitoring. Hence, the findings do not lend any support for hypotheses $3 \mathrm{a}$ and 3b (see Model 3 and Model 6 respectively).

When testing the moderating effect of CHQ involvement we get support for hypotheses $4 \mathrm{a}$ and $4 \mathrm{~b}$. The findings show that the effect of knowledge ambiguity on transfer efficiency (Model 3) and transfer effectiveness (Model 6) is negatively moderated by CHQ involvement. The results also show that the effect of contextual constraints on transfer efficiency (Model 3) as well as on transfer effectiveness (Model 6) is negatively moderated by CHQ involvement. Hence, both hypotheses $5 \mathrm{a}$ and $5 \mathrm{~b}$ are supported. Finally, the effect of resource constraints on transfer efficiency is positively moderated by CHQ involvement (Model 3). However CHQ involvement does not moderate the effect of resource constraints on transfer 
effectiveness (Model 6). We therefore find support for hypothesis 6a but not for hypothesis $6 b$.

\section{Discussion}

This paper addresses the literature on the value added role of CHQ management of subsidiary level activities (e.g., Egelhoff 2010; Goold and Campbell 2002; Poppo 2003). We examine the value added of CHQ monitoring and CHQ involvement during innovation transfer process at the subsidiary level and the issue of these being for a 'good' or a 'bad' cause (cf. Foss et al. 2012). The value-added of these two managerial approaches is viewed in terms of their impact on the success of the transfer process, e.g., the efficiency and the effectiveness of the process. Our overarching aim was to address the lack of research on the value added role of these strategies used by CHQ to manage innovation transfer processes, in particular under certain 'sticky' transfer conditions. This is done by emphasizing the knowledge situation of the CHQ and how this is related to the value added nature of CHQ management of innovation transfer processes at the subsidiary level. To conclude, this study has more systematically tested and discussed the important link between corporate intentions, transfer contingencies and transfer performance than has been done in previous studies.

\subsection{Findings}

Considering the use of CHQ monitoring in sticky transfer environments, the results show that there is a negative moderating effect of CHQ monitoring on both the efficiency and the effectiveness of innovation transfer in situations when the subsidiaries are facing contextual constraints. This lend support for the argument that if the CHQ uses monitoring, that is acts as an 'outsider' in a context of confusion, it will only impede the ability of the involved participants to improve performance. The results also show that CHQ monitoring has a negative impact on the innovation transfer efficiency in situations of high knowledge ambiguity, i.e. a high uncertainty of the inherent technology. This highlights the fact that the CHQ may have an overconfidence of the subsidiaries role in the process which may only lead to confusion and demotivation and may slow down transfer processes (cf. Forsgren and Holm 2010; Verbeke and Greidanus 2009).

The study did not lend any support for the suggestion that there is a negative impact of CHQ monitoring on the effectiveness of innovation transfers when facing knowledge ambiguity. The non-significant result may be due to the simple reason that there are no ex ante expectations of a satisfactory transfer process when the focal innovation are new and very complex to the receiving subsidiaries. Contrary to our expectation, the results show that if the innovation transfer process of the subsidiaries was imposed with resource constraints, then CHQ monitoring seems to be adequate "enough" to provide both transfer efficiency and effectiveness. We find the results rather interesting, especially with regard to the view of the disadvantages of hands-off parenting through control rather than active involvement (Forsgren and 
Holm 2010). As stated by Goold and Campbell (2002, p. 222), the value-adding role of the parent relies on "being more involved in guiding co-ordination between units". One possible reason for this result may simply be that if the transfer processes are not heavily dependent on headquarters possession of appropriate knowledge then CHQ monitoring may be for a good cause as long as it is perceived as reasonable fair and does, for instance, not break any psychological contracts (cf. Rousseu and Parks 1993).

Turning to the impact of CHQ involvement on innovation transfer performance, the results, as predicted, show that there is a negative moderating effect of CHQ involvement on transfer efficiency as well as effectiveness in situations where the subsidiaries are facing contextual barriers. This give support to the notion that losses in efficiency and effectiveness can be related to what Verbeke and Greidanus (2009) call 'opportunistic bounds on reliability,' whereby the CHQ make ex ante commitments in good faith based on a hunch rather than deep knowledge or insight, which may increase the "likelihood of reordering of preferences after an original commitment is made" (Verbeke and Greidanus 2009 , p. 1483). Opposed to what has been suggested, this result indicates that headquarters, even if it is an 'insider', is not in a position to add value to innovation transfer processes if it lacks an understanding of the specific transfer context (cf. Dellestrand and Kappen 2012; Miao et al. 2016). Hence, our study provides evidence in line with Chung (2014) that a managerial intention to 'do good' is not enough, it is important to understand the underlying contingencies affecting headquarters intention.

The results of this study lend support for the suggestion that the CHQ is able to add value to innovation transfer processes in terms of an increased efficiency in situations where the processes are constrained by a lack of tangible resources. This supports the notion that the impact of uncertainty is less pronounced in situations where a lack of tangible support and resources is the main barrier to successful transfer. Hence, an active involvement of the CHQ has the ability to actually speed up the transfer process and reduce the costs of the process. However, we could not find any positive moderating effect of CHQ involvement on the transfer effectiveness when the transfer process was constrained by resource deficits. There are two possible reasons behind this result. First, the used measurement of CHQ involvement does not specify the actual amount of support and involvement (e.g., time, resources and money spend on the innovation transfer). Hence, we have unfortunately not been able to capture explicitly the quantity and the quality of the involvement of the CHQ. Secondly, the result may also reflect the fact an active involvement of the CHQ without any actual targeted actions and activities does not give rise to a satisfactory completion and implementation of the innovation at the receiving subsidiaries (cf. Chung 2014).

It can be concluded that the characteristics of the investigated MNC subsidiaries do not influence the innovation transfer performance as could be expected. For instance, the previous relationship history of the sending and receiving units (in terms of the duration and level of previous relationship) reveals no effect on transfer efficiency. This is a bit surprising. One explanation for this could be that there is an 
inherent context specificity of the experience gained from collaborating and sharing knowledge on a more daily basis, which is difficult to incorporate and make use of in a specific focal innovation project.

\subsection{Theoretical Implications}

Theoretically, our findings can be interpreted as supporting Forsgren et al's (2005, 2010) suggestion that CHQ has limited knowledge and thus a limited ability to influence the behavior and the processes of their foreign subsidiaries. Due to this, the CHQ ability to influence innovation transfer processes may be considerably constrained. More specifically, the results suggest that CHQ can influence the outcome of innovation transfer processes by tailoring their managerial approach in relation to the underlying conditions characterizing the transfer processes and their knowledge and understanding of these particular conditions. Hence, our study contributes to the research on the network MNC suggesting that the ability of the headquarters to successfully add value to intracorporate transfer processes has to be understood in the light of its 'knowledge situation' (Forsgren and Holm 2010). It is interesting that headquarters are able to pinpoint important innovation projects but do not seem to be able to provide any substantial increase in innovation transfer performance as they get involved in the project.

As highlighted in this paper, the CHQ in the network MNC is an outsider suffering under the liability of uncertainty and may in certain circumstances, for different reasons, be bounded reliable. The results of this study give reason to believe that although headquarters may be involved in subsidiary activities for a good cause there is a high likelihood of value destruction. In a recent article by to Foss et al. (2012) the authors claim that the general assumption of headquarters benevolence needs to be modified, particularly in less formalized network MNCs. "The dominant assumption of the MNC literature that CHQs are benevolent is a strong assumption, as selective intervention hazard may be substantial" (Foss et al. 2012, p. 257). In line with this research, our findings implies that intervention hazards may occur since the CHQ lack adequate, relevant and useful knowledge, and may end up being over-committed and overconfident in its own abilities. If the headquarters possess relevant and useful knowledge it will be in a stronger position to evaluate the significance of their involvement in terms of when, where and how, and thus act in a less opportunistic manner relative to the subsidiaries. In this context, there is a substantial body of research in social studies and motivational psychology (e.g., intervention theory) that studies the problem of intervention for securing desired outcomes. For instance, Argyris' (1970) intervention theory addresses the issue of when it is desirable to intervene and when it is not appropriate. He argues that successful intervention depends on appropriate and useful knowledge. In line with this suggestion, our results give reason to believe that intervention in terms of CHQ involvement in combination with a lack of relevant and useful knowledge may be perceived as demotivating rather than supporting. In other words, if the CHQ involves itself in innovation processes at the subsidiary level 
despite a lack of relevant knowledge rather than because of it, such participation will be of much less value added than the parenting theory suggests (Campbell et al. 1995; Goold et al. 1994, 1998).

\subsection{Limitations and Implications for Managers and Future Research}

Although we believe that our study contributes to the research on the value-adding role of MNC corporate headquarters for subsidiary knowledge transfer behavior, the current paper is not without limitations. Most notably the one-sided view of this phenomenon where the information is only based on the "sending" subsidiaries may give rise to problems of common method bias. In an effort to reduce the problems associated with this approach, the questionnaire was answered by multiple respondents at the sending subsidiaries. In addition, in order to control for the self-assessment bias of the data, we used a face-to-face data collection technique. Although this does not remove the problem we believe it reduces it to a great extent. A second limitation stems from the fact that we have not been able to explicitly test the knowledge situation of the CHQ. This calls for future studies on the link between headquarters' actual knowledge, understanding and experience of subsidiary-level activities, and their commitments. This could be made with proxies such as knowledge about the innovation processes (development and transfer) in terms of its technical context, organizational context, and relational- and cognitive context. A third limitation is based on our quite blunt measurement of the headquarters functions. A more fine grained measurement of the active managerial function would be helpful in order to distinguish between whether headquarters listens, offer guidance, has good communication skills, and is open to new ideas etc.

Our findings provide some important implications for the role of top management in knowledge transfer activities. One managerial implication that can be drawn from this study is that when the CHQ does not have sufficient and relevant knowledge about the innovation transfer process, an active managerial function is as inefficient as a monitoring function with regard to the efficiency of innovation transfer processes. If corporate managers involve themselves without useful knowledge or forethought, it could easily overestimate the potential outcomes of subsidiary level activities, thus possibly destroying rather than adding value to them. This corresponds to research on the psychology of power and the 'illusion of control' (e.g., Langer 1975). It is argued that power often has farreaching effects and is related to the sense of control, rather than control as such. From this point of view the 'powerful' headquarters' possession of control may impede learning and predispose toward greater risk taking behavior. Although research within the network tradition suggests that MNCs today are more democratized organizations, our study implies that corporate management still is stuck in a 'control and command leadership' (cf. Tallman and Koza 2010). The CHQ should carefully consider the 'how' of managing innovation transfer processes at the subsidiary level, e.g., that a direct or an indirect management is dependent on the specific conditions under which the transfer takes place. This is in line with Stewardt et al. (2015) arguing for a higher awareness among IB 
scholars as well as mangers of the overall contextual contingencies in which transfer activities occur.

The control variable 'subsidiary location' that captured the spatial distance between a focal subsidiary and other subsidiaries within the MNC showed no direct negative effect on transfer efficiency as expected. Hence, in this study we did not find support for the suggestion that subsidiary-level activities, in general, become more costly as the spatial distance increases (cf. Asmussen and Goerzen 2013; Baaij and Slangen 2013). However, one could expect that the 'negative' direct effect of CHQ monitoring as well as CHQ involvement would be particularly evident as the geographic distance increases. It has in fact been suggested that personal behavioral monitoring may be less effective than for instance output monitoring for the purpose of knowledge exchange as such geographic disaggregation of the CHQ increases (Baaij and Slangen 2013).

Since this study is limited to the study of the CHQ as one single entity in a specific geographic location, future research could benefit from studies of the impact of the evolving re-organization of parenting activities, in terms of the consequences of CHQ disaggregation, on the strategic management on innovations in MNCs. In relation to this, research has also discussed vertical disaggregation in terms of the opportunities of relieving CHQ of this burden of controlling and coordinating dispersed subsidiaries through the delegation of CHQ's functions to sub-levels such as the regional, divisional and subsidiary level (Mahnke et al. 2012; Alfoldi et al. 2012; Piekkari et al. 2010). The existence of multiple headquarters may imply a more diverse set of capabilities and knowledge being deployed in innovation projects, which will have an effect on the end result of a transfer processes. An interesting avenue for future research would be to investigate the effect of such delegation of headquarters functions on the development and transfer of innovations in MNCs. Finally, it would be interesting to know more about the antecedents, e.g., the different interests and motivations, among the corporate managers to actively involve themselves in subsidiary-level activities, in particular innovation projects and processes. While prior studies have been occupied with the effect of corporate parenting, future studies pursing this line of inquiry could have the potential to make a contribution to management research in general and transfer management in MNCs in particular.

Acknowledgements We would like to thank Professor Mats Forsgren and two anonymous reviewers for insightful comments and suggestions. We also appreciate the financial support from Handelsbankens Research Foundations. Funding was provided by Jan Wallanders och Tom Hedelius Stiftelse samt Tore Browaldhs Stiftelse.

Open Access This article is distributed under the terms of the Creative Commons Attribution 4.0 International License (http://creativecommons.org/licenses/by/4.0/), which permits unrestricted use, distribution, and reproduction in any medium, provided you give appropriate credit to the original author(s) and the source, provide a link to the Creative Commons license, and indicate if changes were made. 


\section{Appendix}

Operationalization of the constructs and construct reliability

\begin{tabular}{|c|c|c|c|c|c|}
\hline Construct & Scale & $\begin{array}{l}\text { Factor } \\
\text { loading }\end{array}$ & $\begin{array}{l}\text { Cronbach's } \\
\text { alpha }\end{array}$ & $\begin{array}{l}\text { MIC } \\
\text { value }\end{array}$ & References \\
\hline \multicolumn{6}{|l|}{ Dependent variables } \\
\hline Transfer efficiency & & & \multirow[t]{5}{*}{0.75} & \multirow[t]{5}{*}{ NA } & \multirow{5}{*}{$\begin{array}{l}\text { Ciabuschi et al. (2011), } \\
\text { Hansen et al. (2005), } \\
\text { Szulanski (1996), } \\
\text { Yamin et al. (2011), } \\
\text { Zander and Kogut } \\
\text { (1995) }\end{array}$} \\
\hline $\begin{array}{l}\text { 1. Counterpart have started } \\
\text { using the innovation very } \\
\text { quickly }\end{array}$ & $1-7$ & 0.78 & & & \\
\hline $\begin{array}{l}\text { 2. Starting point of the } \\
\text { innovation transfer was much } \\
\text { earlier than expected }\end{array}$ & $1-7$ & 0.79 & & & \\
\hline $\begin{array}{l}\text { 3. First day of innovation used } \\
\text { by the receiver was much } \\
\text { earlier than expected }\end{array}$ & $1-7$ & 0.84 & & & \\
\hline $\begin{array}{l}\text { 4. Actual costs of innovation } \\
\text { transfer were much lower } \\
\text { than expected }\end{array}$ & $1-7$ & 0.60 & & & \\
\hline Transfer effectiveness & & & \multirow[t]{4}{*}{0.73} & \multirow[t]{4}{*}{ NA } & \multirow{4}{*}{$\begin{array}{l}\text { Daft (1998), Lane and } \\
\text { Lubatkin (1998), Lord } \\
\text { and Ranft }(2000), \\
\text { Simonin (1999, 2004), } \\
\text { Yamin et al. (2011) }\end{array}$} \\
\hline $\begin{array}{l}\text { 1. To what extent the } \\
\text { innovation transfer has been } \\
\text { completed between your unit } \\
\text { each of the following } \\
\text { counterparts }\end{array}$ & $1-7$ & 0.75 & & & \\
\hline $\begin{array}{l}\text { 2. Innovation has been very } \\
\text { easy to adopt by this } \\
\text { counterpart }\end{array}$ & $1-7$ & 0.82 & & & \\
\hline $\begin{array}{l}\text { 3. Performance of the } \\
\text { innovation transfer process } \\
\text { was very satisfactory }\end{array}$ & $1-7$ & 0.84 & & & \\
\hline \multicolumn{6}{|l|}{ Independent variables } \\
\hline $\begin{array}{l}\text { Knowledge ambiguity with } \\
\text { regard to the innovation } \\
\text { transferred }\end{array}$ & & & \multirow[t]{5}{*}{0.72} & \multirow[t]{5}{*}{ NA } & \multirow{5}{*}{$\begin{array}{l}\text { Bresman et al. (1999), } \\
\text { Reed and DeFillippi } \\
\text { (1990), Simonin (1999), } \\
\text { Winter (1987), Zander } \\
\text { and Kogut (1995) }\end{array}$} \\
\hline $\begin{array}{l}\text { 1. The innovation comprises } \\
\text { technology that is new to } \\
\text { your unit }\end{array}$ & $1-7$ & 0.71 & & & \\
\hline $\begin{array}{l}\text { 2. The innovation comprises a } \\
\text { high variety of knowledge } \\
\text { bases (e.g., chemistry, } \\
\text { physics, engineering) }\end{array}$ & $1-7$ & 0.67 & & & \\
\hline $\begin{array}{l}\text { 3. To develop the innovation } \\
\text { technology/process know- } \\
\text { how, you had to invest } \\
\text { significantly in specialized } \\
\text { equipment and facilities }\end{array}$ & $1-7$ & 0.79 & & & \\
\hline $\begin{array}{l}\text { 4. To develop the innovation } \\
\text { technology/process know- } \\
\text { how, you had to invest } \\
\text { significantly in skilled human } \\
\text { resources }\end{array}$ & $1-7$ & 0.79 & & & \\
\hline
\end{tabular}


continued

\begin{tabular}{|c|c|c|c|c|c|}
\hline Construct & Scale & $\begin{array}{l}\text { Factor } \\
\text { loading }\end{array}$ & $\begin{array}{l}\text { Cronbach's } \\
\text { alpha }\end{array}$ & $\begin{array}{l}\text { MIC } \\
\text { value }\end{array}$ & References \\
\hline $\begin{array}{l}\text { Contextual constraints with } \\
\text { regard to the transfer of } \\
\text { innovation: }\end{array}$ & & & \multirow[t]{5}{*}{0.73} & \multirow[t]{5}{*}{ NA } & \multirow{5}{*}{$\begin{array}{l}\text { Allen (1977), Katz and } \\
\text { Allen (1982), } \\
\text { Lichtenthaler and Ernst } \\
\text { (2006), Szulanski } \\
\text { (1996) }\end{array}$} \\
\hline $\begin{array}{l}\text { 1. You hesitate to transfer the } \\
\text { innovation as you will lose } \\
\text { your advantage within the } \\
\text { MNC }\end{array}$ & $1-7$ & 0.64 & & & \\
\hline $\begin{array}{l}\text { 2. Counterpart hesitates to } \\
\text { receive the innovation as it } \\
\text { was not invented by them }\end{array}$ & $1-7$ & 0.73 & & & \\
\hline $\begin{array}{l}\text { 3. Technical difference makes } \\
\text { transfer problematic }\end{array}$ & $1-7$ & 0.77 & & & \\
\hline $\begin{array}{l}\text { 4. Organizational difference } \\
\text { makes transfer problematic }\end{array}$ & $1-7$ & 0.82 & & & \\
\hline $\begin{array}{l}\text { Resource constraints with regard } \\
\text { to the transfer of innovation }\end{array}$ & & & \multirow[t]{3}{*}{0.71} & \multirow[t]{3}{*}{ NA } & \multirow{3}{*}{$\begin{array}{l}\text { Lin et al. (2008), } \\
\text { Minbaeva and } \\
\text { Michailova (2004), } \\
\text { Szulanski (1996) }\end{array}$} \\
\hline $\begin{array}{l}\text { 1. Lack of necessary resources } \\
\text { (efforts, time and resources) } \\
\text { within your unit to put in this } \\
\text { specific relationship makes } \\
\text { the transfer difficult }\end{array}$ & $1-7$ & 0.88 & & & \\
\hline $\begin{array}{l}\text { 2. Lack of necessary resources } \\
\text { (efforts, time and resources) } \\
\text { within the counterpart to put } \\
\text { in this specific relationship } \\
\text { makes the transfer difficult }\end{array}$ & $1-7$ & 0.88 & & & \\
\hline CHQ monitoring & & & \multirow[t]{4}{*}{0.73} & \multirow[t]{4}{*}{ NA } & \multirow{4}{*}{$\begin{array}{l}\text { Balkin and Gomez-Mejia } \\
\text { (1987), Galbraith and } \\
\text { Merrill (1991), Fey and } \\
\text { Furu (2008) }\end{array}$} \\
\hline $\begin{array}{l}\text { 1. Financial bonuses are given } \\
\text { to individuals for sharing } \\
\text { knowledge with co-workers }\end{array}$ & $1-7$ & 0.80 & & & \\
\hline $\begin{array}{l}\text { 2. Individuals with the } \\
\text { reputation for sharing } \\
\text { knowledge with others are } \\
\text { favoured for promotion }\end{array}$ & $1-7$ & 0.77 & & & \\
\hline $\begin{array}{l}\text { 3. Employees are fully aware of } \\
\text { all the bonuses that may be } \\
\text { received for knowledge } \\
\text { sharing }\end{array}$ & $1-7$ & 0.85 & & & \\
\hline
\end{tabular}


continued

\begin{tabular}{|c|c|c|c|c|c|}
\hline Construct & Scale & $\begin{array}{l}\text { Factor } \\
\text { loading }\end{array}$ & $\begin{array}{l}\text { Cronbach's } \\
\text { alpha }\end{array}$ & $\begin{array}{l}\text { MIC } \\
\text { value }\end{array}$ & References \\
\hline CHQ involvement & & & 0.69 & 0.37 & Ciabuschi et al. (2011), \\
\hline $\begin{array}{l}\text { 1. MNC HQ has formally } \\
\text { instructed you to share this } \\
\text { innovation with the } \\
\text { counterpart }\end{array}$ & $1-7$ & 0.80 & & & $\begin{array}{l}\text { Dellestrand and Kappen } \\
\text { (2012), Yamin et al. } \\
\text { (2011) }\end{array}$ \\
\hline $\begin{array}{l}\text { 2. MNC HQ have themselves } \\
\text { been heavily involved in } \\
\text { conducting the actual transfer } \\
\text { process with the counterpart }\end{array}$ & $1-7$ & 0.80 & & & \\
\hline $\begin{array}{l}\text { 3. MNC HQ have taken the } \\
\text { complete responsibility for } \\
\text { the transfer of this innovation } \\
\text { to this counterpart }\end{array}$ & $1-7$ & 0.71 & & & \\
\hline $\begin{array}{l}\text { 4. With regard to transfer of the } \\
\text { innovation, to what extent is } \\
\text { this driven by the } \\
\text { requirement from HQ }\end{array}$ & $1-7$ & 0.60 & & & \\
\hline \multicolumn{6}{|l|}{ Control variables } \\
\hline Age of relationship & & & NA & NA & Fey and Furu (2008) \\
\hline $\begin{array}{l}\text { Age of relationship between } \\
\text { your unit and the divisional/ } \\
\text { business area and/or MNC } \\
\text { units that have received the } \\
\text { innovation }\end{array}$ & Year & NA & & & \\
\hline Previous relationship & & & 0.72 & NA & March and Simon (1958), \\
\hline $\begin{array}{l}\text { 1. To what extent have you } \\
\text { previously (beside this } \\
\text { innovation) cooperated } \\
\text { together with the } \\
\text { counterparts (receiving units) }\end{array}$ & $1-7$ & 0.82 & & & $\begin{array}{l}\text { Nelson and Winter } \\
\text { (1982), Szulanski } \\
\text { (1996) }\end{array}$ \\
\hline $\begin{array}{l}\text { 2. To what extent have you } \\
\text { previously (beside this } \\
\text { innovation) shared } \\
\text { knowledge together with the } \\
\text { counterparts (receiving units) }\end{array}$ & $1-7$ & 0.84 & & & \\
\hline $\begin{array}{l}\text { 3. To what extent existing } \\
\text { routines of sharing } \\
\text { knowledge with this } \\
\text { counterpart drove innovation } \\
\text { transfer? }\end{array}$ & $1-7$ & 0.75 & & & \\
\hline Relevance of innovation & & & 0.76 & NA & \\
\hline $\begin{array}{l}\text { 1. Importance of the innovation } \\
\text { to your unit }\end{array}$ & $1-7$ & 0.65 & & & $\begin{array}{l}\text { Schulz (2003), Björkman } \\
\text { et al. (2004) }\end{array}$ \\
\hline $\begin{array}{l}\text { 2. Importance of the innovation } \\
\text { to the division/business area } \\
\text { as a whole }\end{array}$ & $1-7$ & 0.94 & & & \\
\hline $\begin{array}{l}\text { 3. Importance of the innovation } \\
\text { to the MNC as a whole }\end{array}$ & $1-7$ & 0.87 & & & \\
\hline
\end{tabular}


continued

\begin{tabular}{llllll}
\hline Construct & Scale & $\begin{array}{l}\text { Factor } \\
\text { loading }\end{array}$ & $\begin{array}{l}\text { Cronbach's } \\
\text { alpha }\end{array}$ & $\begin{array}{l}\text { MIC } \\
\text { value }\end{array}$ & References \\
\hline $\begin{array}{l}\text { Subsidiary location (of sending } \\
\text { and receiving units) }\end{array}$ & & NA & NA & $\begin{array}{c}\text { Ambos and Ambos } \\
(2009), \text { Bhagat et al. } \\
\text { (2002), Ghemawat } \\
\text { (2001) }\end{array}$ \\
$\begin{array}{l}\text { 1. The country location of } \\
\text { sending unit }\end{array}$ & 0 or & NA & & \\
$\begin{array}{l}\text { 2. The country location of the } \\
\text { receiving unit (the counterpart) } \\
\text { (dummy where innovation has } \\
\text { been transferred between } \\
\begin{array}{l}1=\text { Western to Asian } \\
\text { subsidiaries and 0 = Western } \\
\text { to Western subsidiaries) }\end{array}\end{array}$ & & & & \\
\end{tabular}

\section{References}

Aitken, L. S., \& West, S. G. (1991). Multiple Regressions: Testing and Interpreting Interactions. Newbury Park: Sage.

Alfoldi, E. A., Clegg, L. J., \& McGaughey, S. L. (2012). Coordination at the edge of the empire: The delegation of headquarters functions through regional management mandates. Journal of International Management, 18(3), 276-292.

Allen, T. J. (1977). Managing the Flow of Technology. Cambridge: MIT Press.

Ambos, T., \& Ambos, B. (2007). Organizing the discontinuous knowledge flows: A new perspective on the management of knowledge and innovation in MNCs. In S. Tallman (Ed.), A New Generation in International Strategic Management (pp. 142-161). London: Edward Elgar.

Ambos, T., \& Ambos, B. (2009). The impact of distance on knowledge transfer effectiveness in multinational corporations. Journal of International Management, 15(1), 1-14.

Ambos, T., Ambos, B., \& Schlegelmilch, B. B. (2006). Learning from foreign subsidiaries: An empirical investigation of headquarters' benefits from reverse knowledge transfers. International Business Review, 15(4), 294-312.

Ambos, B., \& Mahnke, V. (2010). How do MNC headquarters add value? Management International Review, 50(4), 403-412.

Andersson, U., Forsgren, M., \& Holm, U. (2007). Balancing subsidiary influence in the federative MNC: A business network view. Journal of International Business Studies, 38(5), 802-818.

Andersson, U., \& Holm, U. (2010). Managing the Contemporary Multinational: The Role of Headquarters. Cheltenham: Elgar.

Argyris, C. (1970). Intervention Theory and Method: A Behavioral Science View. Reading: AddisonWesley.

Asmussen, C. G., \& Goerzen, A. (2013). Unpacking dimensions of foreignness: Firm-specific capabilities and international dispersion in regional, cultural, and institutional space. Global Strategy Journal, $3(2), 127-149$.

Baaij, M. G., \& Slangen, A. H. J. (2013). The role of headquarters-subsidiary geographic distance in strategic decisions by spatially disaggregated headquarters. Journal of International Business Studies, 44(9), 941-952.

Balkin, D. B., \& Gomez-Mejia, L. R. (1987). Toward a contingency theory of compensation strategy. Strategic Management Journal, 8(2), 169-182.

Barner-Rasmussen, W., Piekkari, R., Scott-Kennel, J., \& Welch, C. (2010). Commander in-chief or absentee landlord? Key perspectives on headquarters in multinational corporations. In U. Holm \& U. Andersson (Eds.), Managing the Contemporary Multinational: The Role of Headquarters. Cheltenham: Edward Elgar. 
Bartlett, C. A., \& Ghoshal, S. (1989). Managing Across Borders: The Transnational Solution. Boston: Harvard Business School Press.

Bhagat, R. S., Kedia, B. L., Harveston, P. D., \& Triandis, H. C. (2002). Cultural variations in the crossborder transfer of organizational knowledge: An integrative framework. Academy of Management Review, 27(2), 204-221.

Björkman, I., Barner-Rasmussen, W., \& Li, L. (2004). Managing knowledge transfer in MNCs: The impact of headquarters control mechanisms. Journal of International Business Studies, 35(5), 443-455.

Bouquet, C., \& Birkinshaw, J. (2008). Wight versus voice: How foreign subsidiaries gain attention from corporate headquarters. Academy of Management Journal, 51(3), 577-601.

Bresman, H., Birkinshaw, J., \& Nobel, R. (1999). Knowledge transfer in international acquisitions. Journal of International Business Studies, 30(3), 439-462.

Briggs, S. R., \& Cheek, J. M. (1986). The role of factor analysis in the development and evaluation of personality scales. Journal of Personality, 54(1), 106-148.

Brown, S. L., \& Eisenhardt, K. M. (1995). Product development: Past research, present finding, and future directions. Academy of Management Review, 20(2), 343-378.

Campbell, A., Goold, M., \& Alexander, M. (1995). Corporate strategy: The quest for parenting advantage. Harvard Business Review, 37(2), 120-132.

Chandler, A. D. (1962). Strategy and Structure-Chapters in the History of the Industrial Enterprise. Cambridge: MIT Press.

Chandler, A. (1991). The functions of the headquarters unit in the multi-business firm. Strategic Management Journal, 12(1), 31-50.

Chung, L. (2014). Headquarters managerial intentionality and reverse transfer of practices. Management International Review, 54(2), 225-252.

Ciabuschi, F. (2004). On the Innovative MNC: Leveraging Innovations and the Role of IT Systems, Doctoral Thesis, No. 111. Department of Business Studies, Uniersitetstryckeriet, Uppsala University, Uppsala.

Ciabuschi, F., Dellestrand, H., \& Holm, U. (2012a). The role of headquarters in the contemporary MNC. Journal of International Management, 18(3), 213-223.

Ciabuschi, F., Forsgren, M., \& Martín Martín, O. (2011). Rationality versus ignorance: The role of MNE headquarters in subsidiaries innovation processes. Journal of International Business Studies, 42(7), 958-970.

Ciabuschi, F., Forsgren, M., \& Martín Martín, O. (2012b). Headquarters' involvement and efficiency of innovation development and transfer in multinationals: A matter of sheer ignorance? International Business Review, 21(2), 130-144.

Cohen, W. M., \& Levinthal, D. A. (1990). Absorptive capacity: A new perspective on learning and innovation. Administrative Science Quarterly, 35(1), 128-152.

Collins, J., \& Hitt, M. (2006). Leveraging tacit knowledge in alliances: The importance of using relational capabilities to build and leverage relational capital. Journal of Engineering and Technology Management, 23(3), 147-167.

Collis, D., Young, D., \& Goold, M. (2007). The size, structure and performance of corporate headquarters. Strategic Management Journal, 28(4), 383-405.

Daft, R. L. (1998). Organization Theory and Design. Cincinnati: South-Western College Publishing.

Dellestrand, H., \& Kappen, F. (2012). The effects of spatial and contextual factors on headquarters resource allocation to MNE subsidiaries. Journal of International Business Studies, 43(3), 219-243.

Egelhoff, W. G. (2010). How the parent headquarters adds value to an MNC. Management International Review, 50(4), 413-431.

Fey, C. F., \& Furu, P. (2008). Top management incentive compensation and knowledge sharing in multinational corporations. Strategic Management Journal, 29(12), 1301-1323.

Fishbein, M. (1963). An investigation of the relationships between beliefs about an object and the attitude toward that object. Human Relations, 16(3), 233-240.

Forsgren, M. (1997). The advantage paradox of the multinational corporation. In I. Björkman \& M. Forsgren (Eds.), The Nature of the International Firm: Nordic Contributions to International Business Research (pp. 6-85). Copenhagen: Copenhagen Business School Press.

Forsgren, M., \& Holm, U. (2010). MNC headquarters' role in subsidiaries' value-creating activities: A problem of rationality or radical uncertainty. Scandinavian Journal of Management, 26(4), 421-430.

Forsgren, M., Holm, U., \& Johanson, J. (2005). Managing the Embedded Multinational-A Business Network View. Cheltenham: Edward Elgar. 
Foss, N. J. (1997). On the rationales of corporate headquarters. Industrial and Corporate Change, 6(2), 313-338.

Foss, K., Foss, N. J., \& Nell, P. H. (2012). MNC organizational form and subsidiary motivation problems: Controlling intervention hazards in the network MNC. Journal of International Management, 18(3), 247-259.

Fowler, F. J. (1993). Survey Research Methods (2nd ed.). Newbury Park: Sage Publications.

Galbraith, C. S., \& Merrill, G. B. (1991). The effect of compensation program and structure on SBU competitive strategy: A study of technology-intensive firms. Strategic Management Journal, 12(5), $353-370$.

Ghemawat, P. (2001). Distance still matters: The hard reality of global expansion. Harvard Business Review, 79(9), 137-147.

Goold, M., \& Campbell, A. (2002). Parenting in complex structures. Long Range Planning, 35(3), 219-243.

Goold, M., Campbell, A., \& Alexander, M. (1994). How corporate parents add value to the stand-alone performance of their businesses. Business Strategy Review, 5(4), 33-55.

Goold, M., Campbell, A., \& Alexander, M. (1998). Corporate strategy and parenting theory. Long Range Planning, 31(2), 308-314.

Grant, R. M. (1996a). Toward a knowledge-based theory of the firm. Strategic Management Journal, 17(Winter Special Issue), 109-122.

Grant, R. M. (1996b). Prospering in dynamically-competitive environments: Organizational capability as knowledge integration. Organizational Science, 7(4), 375-387.

Hair, J. F., Balck, W. C., Babin, B. J., Anderson, R. E., \& Tatham, R. L. (2006). Multivariate Data Analysis (6th ed.). New Jersey: Prentice-Hall.

Hansen, M. T. (1999). The search-transfer problem: The role of weak ties in sharing knowledge across organization subunits. Administrative Science Quarterly, 44(1), 82-111.

Hansen, M. T., Mors, M. L., \& Lovås, B. (2005). Knowledge sharing in organizations: multiple networks, multiple phases. Academy of Management Journal, 48(5), 776-793.

Hayek, F. A. (1945). The use of knowledge in society. The American Economic Review, 35(4), 519-530.

Hedlund, G. (1986). The hypermodern MNC: A heterarchy? Human Resource Management, 25(1), 9-35.

Inkpen, A. C. (2000). A note on the dynamics of learning alliances: Competition, cooperation, and relative scope. Strategic Management Journal, 21(7), 775-779.

Jensen, M. C., \& Meekling, W. H. (1976). Theory of the firm: Managerial behavior, agency cost and ownership structure. Journal of Financial Economics, 3(4), 305-360.

Johanson, J., \& Vahlne, J. E. (2009). The Uppsala internationalization process model revisited: From liability of foreignness to liability of outsidership. Journal of International Business Studies, 40(9), 1411-1431.

Kang, O. H. (2013). The Advantage Paradox: Managing Innovation Processes in the Multinational Corporation, Doctoral thesis, No. 159. Department of Business Studies, Uppsala University, Uppsala.

Katz, R., \& Allen, T. J. (1982). Investigating the not-invented-here (NIH) syndrome: A look at the performance, tenure and communication patterns of $50 \mathrm{R} \& \mathrm{D}$ project groups. $R \& D$ Management, 12(1), 7-19.

Kirzner, I. M. (1982). Uncertainty, discovery, and human action: A study of the entrepreneurial profile in the Misesian system. In I. M. Kirzner (Ed.), Method, Process, and AUSTRIAN Economics (pp. 139-159). Washington, DC: Heath.

Ko, D.-G., Kirsch, L. T., \& King, W. R. (2014). Antecedents of knowledge transfer from consultants to clients in enterprise system implementations. MIS Quarterly, 29(1), 59-85.

Kogut, B., \& Zander, U. (1992). Knowledge of the firm, combinative capabilities, and the replication of technology. Organization Science, 3(3), 383-397.

Kostova, T. (1999). Transnational transfer of strategic organizational practices: A contextual perspective. Academy of Management Review, 24(2), 308-324.

Kostova, T., \& Roth, K. (2002). Adoption of an organizational practice by subsidiaries of multinational corporations: Institutional and relational effects. Academy of Management Journal, 45(1), 215-233.

Lane, P. J., \& Lubatkin, M. (1998). Relative absorptive capacity and interorganizational learning. Strategic Management Journal, 19(5), 461-478.

Langer, E. J. (1975). The illusion of control. Journal of Personality and Social Psychology, 32(2), 311-328. 
Levin, D. Z., \& Cross, R. (2004). Mediating role of trust in effective knowledge transfer. Management Science, 50(11), 1477-1490.

Lichtenthaler, U., \& Ernst, H. (2006). Attitudes to externally organizing knowledge management tasks: A review, reconsideration and extension of the NIH syndrome. R\&D Management, 36(4), 367-386.

Lin, C., Tan, B., \& Chang, S. (2008). An exploratory model of knowledge flow barriers within healthcare organizations. Information \& Management, 45(5), 331-339.

Lord, M. D., \& Ranft, A. L. (2000). Organizational learning about new international markets: exploring the internal transfer of local market knowledge. Journal of International Business Studies, 31(4), 573-589.

Mahnke, V., Ambos, B., Nell, P. C., \& Hobdari, B. (2012). How do regional headquarters influence corporate decisions in networked MNCs? Journal of International Management, 18(3), 293-301.

March, J., \& Simon, H. (1958). Organizations. New York: Wiley.

Miao, Y., Zeng, Y., \& Lee, J. Y. (2016). Headquarters resource allocation for inter-subsidiary innovation transfer: The effect of within-country and cross-country cultural differences. Management International Review, 56(5), 665-698.

Minbaeva, D. B., \& Michailova, S. (2004). Knowledge transfer and expatriation in multinational corporations: the role of disseminative capacity. Employee Relations, 26(6), 663-679.

Minbaeva, D., Pedersen, T., Björkman, I., Fey, C. F., \& Park, H. J. (2003). MNC knowledge transfer, subsidiary absorptive capacity, and HRM. Journal of International Business Studies, 34(6), 586-599.

Nelson, R., \& Winter, S. (1982). An Evolutionary Theory of Economic Change. Cambridge: Harvard University Press.

Nonaka, I. (1994). A dynamic theory of organizational knowledge creation. Organization Science, 5(1), 14-37.

O'Donnell, S. W. (2000). Managing foreign subsidiaries: Agents of headquarters, or an interdependent network? Strategic Management Journal, 21(5), 525-548.

Patriotta, G., Castellano, A., \& Wright, M. (2013). Coordination knowledge transfer: Global managers as higher-level intermediaries. Journal of World Business, 28, 515-526.

Penrose, E. T. (1959). The Theory of the Growth of the Firm. Oxford: Basil Blackwell.

Pérez-Nordtvedt, L., Kedia, B. L., Datta, K. D., \& Rasheed, A. A. (2008). Effectiveness and efficiency of cross-border knowledge transfer: An empirical examination. Journal of Management Studies, 45(4), 714-744.

Pérez-Nordtvedt, L., Mukherjee, D., \& Kedia, B. L. (2015). Cross-border learning, technological turbulence and firm performance. Management International Review, 55(1), 23-51.

Persson, M. (2006). The impact of operational structure, lateral integrative mechanisms and control mechanisms on intra-MNE knowledge transfer. International Business Review, 15(5), 547-569.

Piekkari, R., Nell, P., \& Ghauri, P. (2010). Regional management as a system: A longitudinal case study. Management International Review, 50(4), 513-532.

Podsakoff, P. M., \& Organ, D. (1986). Self-reports in organizational research: problems and prospects. Journal of Management, 12(4), 531-544.

Poppo, L. (2003). The visible hands of hierarchy within the M-Form: An empirical test of corporate parenting of internal product exchanges. Journal of Management Studies, 40(2), 403-430.

Postrel, S. (2002). Islands of shared knowledge: Specialization and mutual understanding in problemsolving teams. Organization Science, 13(3), 303-320.

Raab, K. J., Ambos, B., \& Tallman, S. (2014). Strong or invisible hands? Managerial involvement in the knowledge sharing process of globally dispersed knowledge groups. Journal of World Business, 49(1), 32-41.

Reed, R., \& DeFillippi, R. J. (1990). Causal ambiguity, barriers to imitation, and sustainable competitive advantage. Academy of Management Review, 15(1), 88-102.

Roth, K., Schweiger, D., \& Morrison, A. J. (1991). Global strategy implementation at the business unit level: Operational capabilities and administrative mechanisms. Journal of International Business Studies, 22(3), 369-402.

Rousseau, D. M., \& Parks, J. M. (1993). Contracts of individuals and organizations. Research in organizational behaviour, 15, 1-43.

Rugman, A. M., \& Verbeke, A. (2001). Subsidiary-specific advantages in multinational enterprises. Strategic Management Journal, 22(3), 237-250.

Schulz, M. (2001). The uncertain relevance of newness: Organizational learning and knowledge flows. Academy of Management Journal, 44(4), 661-681. 
Schulz, M. (2003). Pathway to relevance: Exploring inflows of knowledge into subunits of multinational corporations. Organizational Science, 14(4), 440-459.

Simonin, B. L. (1999). Ambiguity and the process of knowledge transfer in strategic alliances. Strategic Management Journal, 20(7), 595-623.

Simonin, B. S. (2004). An empirical investigation of the process of knowledge transfer in international strategic alliances. Journal of International Business Studies, 35(5), 407-427.

Spender, J. C. (1996). Making knowledge the basis of a dynamic theory of the firm. Strategic Management Journal, 17(Winter Special Issue), 45-62.

Stewardt, W. H., Ruth, C. M., \& Ledgerwoods, D. R. (2015). Do you know what I know? Intent to share knowledge in the US and Ukraine. Management International Review, 55(6), 737-773.

Szulanski, G. (1996). Exploring internal stickiness: Impediments to the transfer of best practice within the firm. Strategic Management Journal, 17(S2), 27-43.

Szulanski, G. (2000). The process of knowledge transfer: A diachronic analysis of stickiness. Organisational Behavior and Human Decision Process, 82(1), 9-27.

Szulanski, G. (2003). Sticky Knowledge Barriers to Knowing in the Firm. Thousand Oaks: Sage Publications.

Szulanski, G., Cappetta, R., \& Jensen, R. J. (2004). When and how trustworthiness matters: Knowledge transfer and the moderating effect of casual ambiguity. Organization Science, 15(5), 600-613.

Tallman, S., \& Koza, M. (2010). Keeping the global in mind: The evolution of the headquarters role in global multi-business firms. Management International Review, 50(4), 433-448.

Teece, D. J. (1977). Technology transfer by multinational firms: The resource cost of transferring technological know-how. The Economic Journal, 87(346), 242-261.

Teece, D. J. (1986). Profiting from technological innovation. Research Policy, 15(6), 285-305.

Tsoukas, H. (1996). The firm as a distributed knowledge system: a constructionist approach. Strategic Management Journal, 17(S2), 11-25.

Vahlne, J. E., Schweizer, R., \& Johanson, J. (2012). Overcoming the liability of outsidership-The challenge of HQ of the global firm. Journal of International Management, 18(3), 224-232.

van Wijk, R., Jansen, J. P., \& Lyles, M. A. (2008). Inter- and intra-organizational knowledge transfer: A meta-analytic review and assessment of its antecedents and consequences. Journal of Management Studies, 45(4), 830-853.

Verbeke, A., \& Greidanus, N. S. (2009). The end of the opportunism vs trust debate: Bounded reliability as a new envelope concept in research on MNE governance. Journal of International Business Studies, 40(9), 1471-1495.

Williamson, O. E. (1975). Markets and Hierarchies: Analysis and Antitrust Implications. New York: Free Press.

Williamson, D. E. (1985). The Economic Institutions of Capitalism. New York: Free Press.

Winter, S. G. (1987). Knowledge and competence as strategic assets. In D. Teece (Ed.), The Competitive Challenge: Strategies for Industrial Innovation and Renewal (pp. 159-184). Cambridge: Ballinger.

Yamin, M., Tsai, H. S., \& Holm, U. (2011). The performance effects of headquarters' involvement in lateral innovation transfers in multinational corporations. Management International Review, 51(2), $157-177$.

Zahra, S. A., Ireland, R. D., \& Hitt, M. A. (2000). International expansion by new venture firms: International diversity, mode of market entry, technological learning, and performance. Academy of Management Journal, 43(5), 925-950.

Zander, U., \& Kogut, B. (1995). Knowledge and the speed of the transfer and imitation of organizational capabilities: An empirical test. Organization Science, 6(1), 76-92. 